\title{
Current Methodologies and Advances in Bio-ethanol Production
}

\author{
Rastogi M and Shrivastava S* $^{*}$ \\ Amity Institute of Biotechnology, Amity University Uttar Pradesh, India \\ *Corresponding author: Shrivastava S, Amity Institute of Biotechnology, Amity University Uttar Pradesh, Sector 125, Noida 201313, Uttar Pradesh, India
}

Submission: 浅July 03, 2018; Published: 阱 August 21, 2018

\begin{abstract}
Scarcity of non-renewable energy sources has paved need for sustainable and renewable biofuels from biomass. Of all natural resources used for production of biofuel, lignocellulosic biomass (producing second generation biofuel) are most attractive as they are highly abundant and easily available throughout the year. Various measures for maximal and efficient utilization of these lignocellulosic biomass for production of biofuels (bioethanol, biodiesel and biogas) have been taken including pretreatment, saccharification and fermentation process. In the present chapter we have consolidated relevant applications for bioethanol production, which includes a brief overview of the current status and biochemical route towards bioethanol production. Various approaches like tailoring of hydrolytic enzymes to increase the specific activity of particular enzymatic reaction and contributions by prominent scientists for effective utilization of celluloses and hemicelluloses for bioethanol production have been discussed. We have also highlighted the comparison on utilization of simple sugars (hexoses and pentoses) by bacteria and fungi and described the recent advanced techniques utilized for the production of ethanol.
\end{abstract}

Keywords: Bioethanol; Second generation biofuel; Consolidated Bioprocessing (CBP); Simultaneous Saccharification and Co-Fermentation (SSCF); Simultaneous saccharification and fermentation (SSF)

\section{Introduction}

The continuous depletion of fossil fuels has lead to increased concerns regarding economic status, national security and global warming. Alternatively, renewable fuels are being sought to meet the current increasing energy demand of the mankind. Municipal waste and wastes generated as a result of agricultural activities, forestry, etc. are being used for biofuel production (solid, liquid or gaseous fuels) [1]. Primary biofuels like fuel wood are generally used for cooking, heating or production of electricity whereas secondary biofuels such as biodiesel and bioethanol can be blended with primary fuels for their usage and they can be produced through various ways by processing suitable biomasses [2]. Depending upon the source and production technology, biofuels are generally classified as first, second, third and fourth generation biofuels. Fuels obtained from food crops such as sugar, vegetable oil, starch, and animal fats are consolidated as first generation biofuels. It is easy to utilize food crops as feedstock for fuel production but it competes with food consumption and thus poses a negative impact on agricultural areas [3]. Second generation biofuels are produced from non-food crops such as biowastes and lignocellulosic biomass whilst third generation biofuels exploit algae as feedstock. Extensive research is going on in this field to engineer algae in an attempt to increase biofuel production as well as to study algal biodiversity in order to reveal highly competent fuel producing species. The fourth generation biofuels (presently on paper) comprise of electrofuels and photobiological solar fuels. Novel synthetic biology technologies can be used to generate fuels from solar energy and discover inexhaustible, cheap raw materials through biological systems.

Though at an infant stage, these $4 \mathrm{G}$ fuels seem to provide a fundamental breakthrough in biofuel production [4]. To date, ethanol accounts for upto $75 \%$ of the total biofuel use [5]. Bioethanol dominates the market with a sale of 58 billion dollars per year. Nearly $50 \%$ of global sugar is utilized for ethanol production and approximately $\sim 86,000 \mathrm{kton} /$ year ethanol so produced is majorly used for biofuel application [3]. United States and Brazil are the leading producers dominantly using simple substrates such as corn and sugarcane, respectively [6]. Even though India is the second largest producer of sugarcane in the world, it contributes to only $2 \%$ of global bioethanol production. Despite the abundant supply of lignocelluloses, their commercial conversion to ethanol is limited to their recalcitrance (due to lignin sheath) to degradation and unique chemical composition [7]. Primarily, lignocellulosic biomass is converted to ethanol via biochemical process which comprises of four major steps: physicochemical pretreatment, enzymatic hydrolysis of the sugar polymers fermentation of the derived sugars into ethanol and distillation [8]. Lignocellulosic biomass consists of highly crystalline celluloses and heterogeneous hemicelluloses making chemical or physical pretreatment, a mandatory process. This increases the cost of the entire process and thus proves to be a major obstacle for large scale production [8,9]. The biochemical process of bioethanol production requires vigorous glycosyl hydrolases- and ethanol producing microbes, both native and recombinant strains. 
The efficacy of the process and thus bioethanol yield also depend upon the efficient utilization of the released sugars and thereby their conversion to ethanol by different microbes. The pathways of sugar conversion (both hexose and pentose) to ethanol vary from one microorganism to another as shown in Figure 1 and thus play an important role in determining the fate of bioethanol yield [10]. Enzyme performance, co-fermentation of C5 and C6 sugars, reduction of enzyme and investment costs, reduction of process time as well as released inhibitory products during pretreatment are the major challenges associated with biochemical process. In order to produce bioethanol from lignocellulosic biomass, that is economically feasible, sustainable, and competitive with petroleum-based fuels, conventional process steps need to be integrated into consolidated process to avoid maximum production of inhibitory sugar derivatives and achieve high ethanol titres.

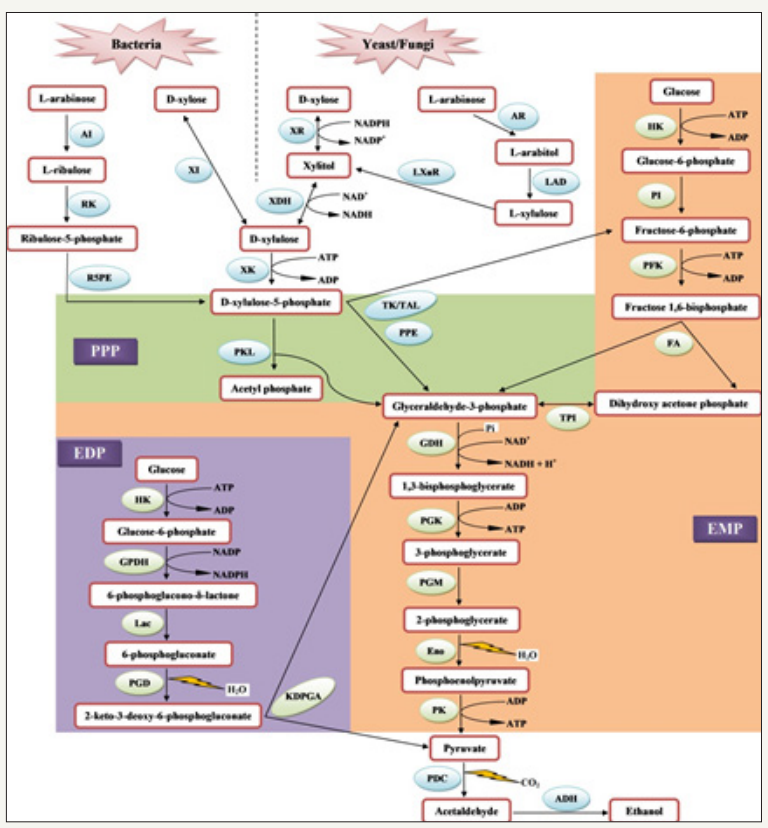

Figure 1: Comparison of hexose (glucose) and pentose (xylose and arabinose) sugar utilization pathways by different microbes.

XK: Xylulose Kinase; PPP: Pentose Phosphate Pathway; XI: Xylose Isomerase; XR: Xylose Reductase; XDH: Xylitol Dehydrogenase; PPE: Phosphopentose Epimerase; TAL: Transaldolase; TK: Transketolase; EMP: Embden-Meyerhof-Parnas Pathway; PKL: Phosphoketolase; AR: Arabinose Reductase; LAD: L-arabitol Dehydrogenase; AI: Arabinose Isomerase; RK: Ribulokinase; R5PE: Ribulose-5-Phosphate-4- Epimerase; TCA: Ttricarboxylic Acid Cycle; HK: Hexokinases; PFK: Phosphofructokinase; FA: Fructose Bisphosphate Aldolase; TPI: Triosephosphate Isomerase; GDH: Phosphate Dehydrogenase; PGK: Phosphoglycerate Kinase; PGM: Phosphoglycerate Mutase; Eno: Enolase; L-XuR: L-xylulose Reductase; PK Pyruvate Kinase; PDC: Pyruvate Decarboxylase; ADH: Alcohol Dehydrogenase; EDP: Entner-Doudoroff Pathway; GPDH: Glucose-6- Phosphate Dehydrogenase; Lac: Lactonase; PGD: 6-Phosphogluconate Dehydratase; KDPG: 2-Keto-3-Deoxy-6- Phosphogluconate; KDPGA: 2-Keto-3-Deoxy-6-Phosphogluconate Aldolase [10].

\section{Bioethanol production from lignocellulosic biomasses}

Bioethanol from lignocellulosic biomass (byproducts of agriculture and related industry) is recognized as one of the most promising alternative for production of renewable and sustainable energy. Lignocellulosic biomass is first pretreated in order to enhance the availability of cellulose, which is confined within the layers of hemicelluloses and lignin. The accessible cellulose and hemicellulose component of the biomass further undergoes saccharification by different enzymes (produced in a separate reactor or externally bought) usually converting them into glucose and xylose, respectively. The hexose and pentose sugars so formed are subsequently converted into bioethanol by a variety of microorganisms via the process of fermentation [11]. In this scenario different integrated methods for hydrolysis and fermentation have been proposed. Separate hydrolysis and fermentation (SHF) is a two-stage process during which the pretreated lignocellulosic biomass is first broken down into monomeric sugars (glucose and xylose) via enzymatic saccharification and further these sugars are converted into ethanol. The only advantage of this process confides in the fact that both enzymatic hydrolysis and fermentation processes operate distinctly at their respective optimum conditions. However, the enzyme activity is inhibited by the accumulation of sugars thereby affecting the ethanol yield $[12,13]$.

Simultaneous saccharification and fermentation (SSF) is an approach, where the saccharification of biomass is combined with simultaneous fermentation of the released sugars in a single reactor. Therefore, as soon as the sugars are formed from biomass, they are rapidly converted into ethanol thus minimising the accumulation of inhibitory sugars in the medium. The process can be easily operated and requires low equipment costs. Also, the presence of ethanol in the broth makes the medium less vulnerable to contamination $[12,14,15]$. Nevertheless, optimization of process 
parameters is difficult as both enzymes and microorganisms work at the same time. For example, cellulolytic enzymes for enzyme hydrolysis work best at around $50{ }^{\circ} \mathrm{C}$ but the optimal conditions for microbes for ethanol fermentation is between $28-37{ }^{\circ} \mathrm{C}$. In such cases, the optimum temperature of enzymes may be lowered through protein engineering but it would be practically difficult, thereby increasing the need of thermo tolerant strains that could grow well and efficiently produce ethanol at high temperature [16].

Simultaneous Saccharification and Co-Fermentation (SSCF) is an integrated process which is oriented to the microbial assimilation of all the sugars formerly released during the pretreatment and hydrolytic processes of lignocellulosic biomass. One strategy can be using mixed cultures of yeasts, that can utilize both hexose and pentose sugars. The only problem is that hexose utilizing microorganisms grow faster than pentose-utilizing microorganisms which leads to higher conversion of hexoses to ethanol. Another alternative is to use a single microorganism capable of optimally assimilating both hexoses and pentoses allowing higher conversion and thus high ethanol yield [17]. This approach offers several advantages like shorter operation time, less cost, lower contamination risk and fewer inhibitory effects during enzymatic hydrolysis [18]. Consolidated bioprocessing or direct microbial conversion (DMC) integrates all the reactions required for the transformation of biomass into ethanol into a single step. In this strategy, only a single microbial community carries out all the processes of enzymes production, enzymatic saccharification and fermentation. This process has numerous advantages like the enzymatic and fermentation processes are entirely compatible and no other capital or operational costs are required for enzyme production. Moreover, whole substrate is consumed solely for the release of sugars. In contrast to the conventionally used yeasts, thermophilic microorganisms offer advantages of utilizing a number of inexpensive biomass feed stocks as well as endure high temperatures. However, their industrial application is limited to low bioethanol tolerance $(<2 \% \mathrm{v} / \mathrm{v})$. Irrespective of this, a thermo tolerant yeast strain $K$. marxianus has been engineered for the co-display of endoglucanase and $\beta$-glucosidase on its cell surface. Not only it could grow at high temperatures $\left(48{ }^{\circ} \mathrm{C}\right)$, but also it can produce ethanol with a yield of $0.47 \mathrm{~g}$ ethanol per gram of consumed carbohydrate from $\beta$-glucan (cellulosic material). On the other hand, mixed cultures can be used that are capable of performing hydrolysis and fermentation of lignocellulosic biomass simultaneously [12].

\section{Bioethanol production using molecular tools and genetically modified organisms}

Up to date, varieties of biofuels are produced from lignocellulosic feedstocks using several engineered hosts. Majority of CBP organisms are generated by either improving biofuel yield of naturally existing cellulose-degrading microorganisms or by engineering cellulolytic microbes to be ethanologenic or ethanologenic microbes to be cellulolytic $[19,20]$. Different species of bacteria like Clostridium thermocellum [21-23], C. phytofermentans [24], C. cellulolyticum [25], Thermoanaerobacterium saccharolyticum [26], Caldicellulosiruptor bescii [27], Escherichia coli [28,29], Zymomonas mobilis [30]; fungi such as Fusarium oxysporum [31], Trichoderma reesei [32], Paecilomyces variotii [33], Aspergillus oryzae [34]; and yeasts including Kluyveromyces marxianus [35,36], Clavispora [37], Pichia stipitis [38,39] and Saccharomyces cerevisiae [40-42] have been studied for their widespread use in bioethanol production (Table 1).

Table 1: Genetically modified microbes for consolidated bioprocess system [10].

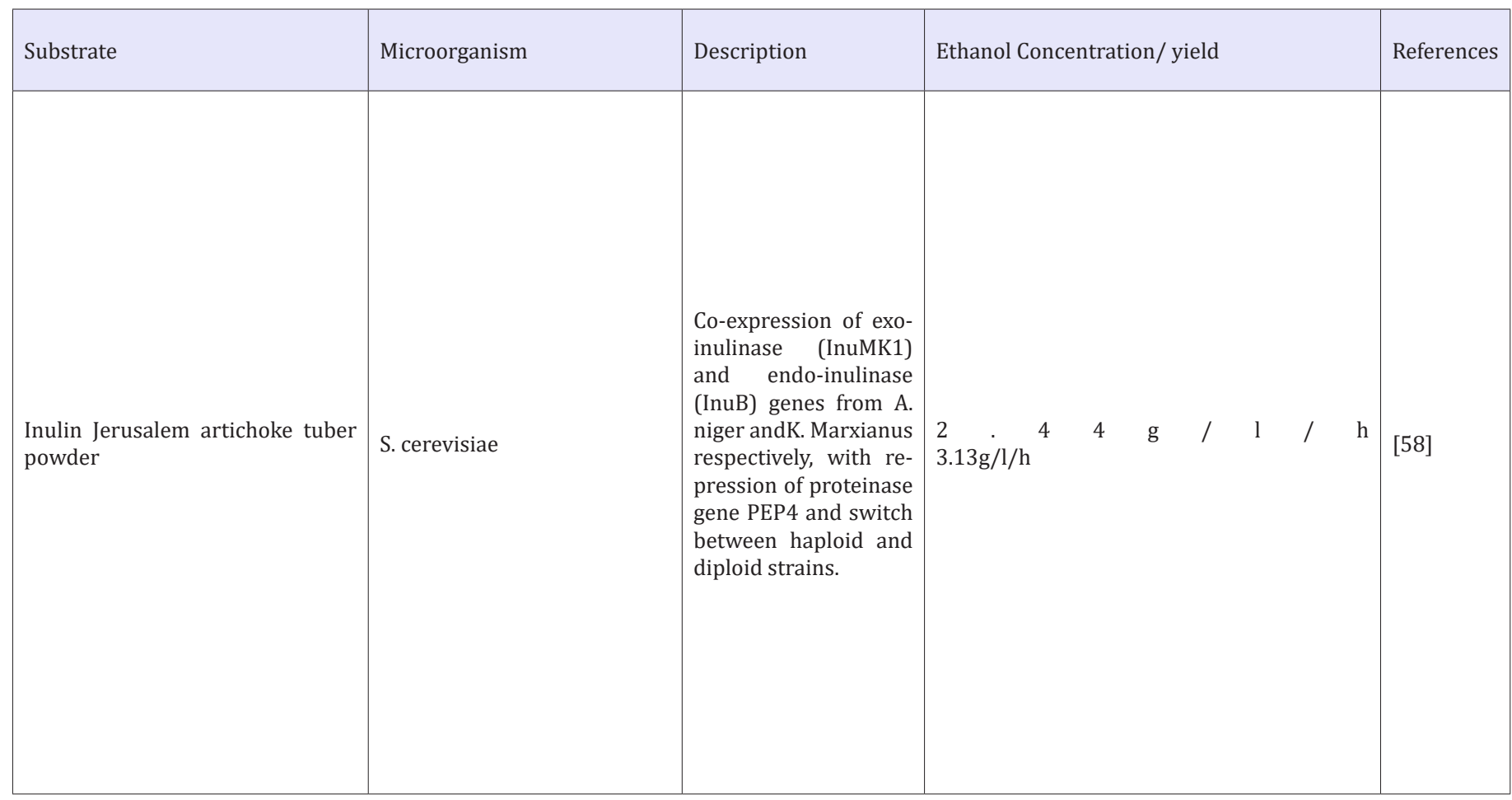




\begin{tabular}{|c|c|c|c|c|}
\hline $\begin{array}{l}2 \quad 0 \quad \mathrm{~g} \quad / \quad r \quad l \\
\text { galactose }+10 \mathrm{~g} / \mathrm{l} \quad \mathrm{CMC} \\
\text { 20g/l galactose }+ \text { PASC }(10 \mathrm{~g} / \mathrm{l})\end{array}$ & S.cerevisiae & $\begin{array}{l}\text { Cell-displayed mini- } \\
\text { cellulosome con- } \\
\text { sisting of endo- and } \\
\text { exo-glucanase with } \\
\text { intracellular cello- } \\
\text { dextrin utilization } \\
\text { pathway mimicking } \\
\text { the one in C. thermo- } \\
\text { cellum }\end{array}$ & 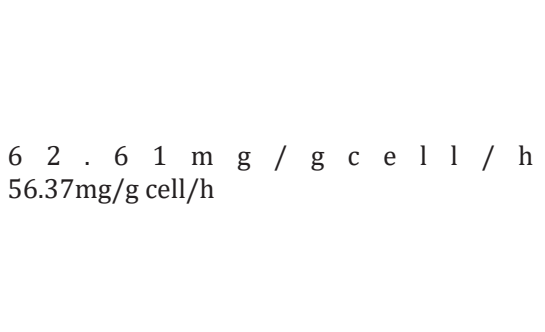 & [42] \\
\hline 60g/l cellulose (Avicel PH105) & C. thermocellum strain AG553 & $\begin{array}{l}\text { Mutation: adaptive } \\
\text { evolution strategy. } \\
\text { Apparent changes } \\
\text { in Clo1313_1831- } \\
\text { 2, AdhE and GapDH } \\
\text { genes in adapted } \\
\text { strain (LL1210). }\end{array}$ & $\begin{array}{l}22.4 \pm 1.4 \mathrm{~g} / \mathrm{l}(75 \% \text { of the theoretical maxi- } \\
\text { mum ) }\end{array}$ & [23] \\
\hline Natural sorghum Triticale & $\begin{array}{l}\text { S.cerevisiae strains M2n and } \\
\text { MEL2 }\end{array}$ & $\begin{array}{l}\text { Integration of codon } \\
\text { optimized variants } \\
\text { of T. lanuginosusglu- } \\
\text { coamylase (TLG1) and } \\
\text { S. fibuligera- } \alpha \text {-amylase } \\
\text { (SFA1) genes }\end{array}$ & 62 and $73 \%$ (theoretical maximum) & {$[55]$} \\
\hline $\begin{array}{l}2 \% \quad(w / v) \\
\text { Switchgrass }\end{array}$ & C. bescii & $\begin{array}{l}\text { Expression of bi- func- } \\
\text { tional acetaldehyde/ } \\
\text { alcohol dehydroge- } \\
\text { nase (AdhE) from T. } \\
\text { pseudethanolicus } 39 \mathrm{E} \\
\text { in the C. bescii strain } \\
\text { lacking lactate dehy- } \\
\text { drogenase gene }\end{array}$ & $\begin{array}{lllll}2 & 3 & \mathrm{~m} & \mathrm{M} \\
1.6 \mathrm{mM} & & & & \end{array}$ & {$[54]$} \\
\hline Xylan and $\beta$-glucan & S.stipitis strain BCC151 91 & $\begin{array}{l}\text { Co-expression of en- } \\
\text { doxylanase and en- } \\
\text { doglucanase from } \\
\text { Aspergillus niger and } \\
\text { Aspergillus aculeatus } \\
\text { respectively }\end{array}$ & $2.7 \mathrm{~g} / \mathrm{l}$ & {$[39]$} \\
\hline $\begin{array}{l}50 \mathrm{~g} / \mathrm{l} \text { Glucose } 50 \mathrm{~g} / \mathrm{l} \text { Sugarcane } \\
\text { bagasse }\end{array}$ & T. reesei CICC 40360 & $\begin{array}{l}\text { Genome shuffling and } \\
\text { mutagenesis to im- } \\
\text { prove production of } \\
\text { ethanol under aero- } \\
\text { bic condition and in- } \\
\text { creased ethanol toler- } \\
\text { ance }(4 \% \mathrm{v} / \mathrm{v})\end{array}$ & $9.7 \mathrm{~g} / 13.1 \mathrm{~g} / \mathrm{l}$ & {$[32]$} \\
\hline
\end{tabular}




\begin{tabular}{|c|c|c|c|c|}
\hline $20 \mathrm{~g} / \mathrm{L} \mathrm{CMC}$ & S.cerevisiae & $\begin{array}{l}\text { Co-expression of en- } \\
\text { doglucanase (eg3) and } \\
\beta \text {-glucosidase (bgl1) } \\
\text { were obtained from } \\
\text { Trichoderma viride }\end{array}$ & $4.63 \mathrm{~g} / \mathrm{l}$ & [56] \\
\hline Wheat straw & F. oxysporum & $\begin{array}{l}\text { Post-translational } \\
\text { gene silencing of the } \\
\text { sugar transporter } \\
\text { (Hxt) in the fungus }\end{array}$ & $33.8 \%$ (theoretical maximum) & {$[31]$} \\
\hline $10 \mathrm{~g} / \mathrm{l}$ crystalline cellulose & C. cellulolyticum & $\begin{array}{l}\text { Inactivation of L-lac- } \\
\text { tate dehydrogenase } \\
\text { (ldh) and L-malate } \\
\text { dehydrogenase (mdh) } \\
\text { genes }\end{array}$ & $2.7 \mathrm{~g} / \mathrm{l}$ & [25] \\
\hline
\end{tabular}

Genetic modifications in microorganisms may sometimes lead to loss in activity and robustness of enzymes. In this scenario, a microbial consortium rather than a single microbe could be used to perform CBP, utilizing the substrate more efficiently thereby increasing product yield. [43] proposed a consortium in a biofilm membrane reactor comprising Trichoderma reesei, for enzyme secretion; Saccharomyces cerevisiae, to ferment hexose (C6) sugars; and Scheffersomyces stipitis, to utilize pentose (C5) sugars, and convert lignocellulosic biomass to ethanol. The aerobic fungi grew directly on the dense oxygen permeable membrane, producing enzymes which hydrolyze the cellulose and hemicelluloses in the biomass to release sugars. Secreted enzyme is only transported from the gas phase through the membrane creating an oxygen gradient and leaving the upper part of the biofilm oxygen depleted. The released sugars are then fermented to ethanol by the anaerobically growing yeast cells. This model could produce ethanol with a $69 \%$ yield $(9.8 \mathrm{~g} / \mathrm{L})$ from whole slurry dilute acid pretreated wheat straw [43]. The control of consortium and difficulty to find identical fermentation conditions for all concerned strains are the major challenges associated with this approach. However, the application of diverse strains will not only aid in the utilization of a broader range of substrates but also produce more enzymes and efficiently utilize C5 and C6 sugars. Conventional genomic, transcriptomic, proteomic techniques fail to provide accurate insights of functional cellular processes and regulatory networks in organisms. Such knowledge could help in identifying new organisms as well as enzymes with desired potential applicable to biofuel industry [44]. Activity-based protein profiling, popularly ABPP is a chemical biology probe-based technology to study enzymatic activity in complex proteomes. The chemical probes react with the active site of a specific target protein (or protein family) in a mechanism-based manner to selectively identify only the active forms of target enzyme. ABPP technique also facilitates in identifying and characterizing unknown protein functions as well as study changes in enzyme activity under different conditions. Other applications include discovery of new biofuel pathways and spotting protein targets of covalently binding natural products [45]. Glycoside hydrolases (GHs) are necessary for hydrolysis of lignocelluloses. Thus, a GH activity-based probe (GH-ABP) would be highly beneficial in identifying and quantifying cellulolytic enzymes that are functionally active in native secreted proteomes as well as give an idea about the synergistic interactions between GH enzymes in vitro, in situ and in vivo.

Chauvigné-Hines et al. [46] used a suite of GH-ABPs (difluoromethylphenyl aglycone, 2-deoxy-2-fluoroglycoside, and $\mathrm{N}$-halogenated glycosylacetamide) to directly label the cell-adherent cellulosome in Clostridium thermocellum (a model anaerobic thermophilic organism). In this study, besides successfully quantifying 177 glycoside hydrolases they were able to study sugar catabolism in the organism due to the off-target labeling incurred as a result of the reactivity of two of the probe types employed [46]. Anderson et al. [47] conducted a study using GH-probe in Trichoderma reesei wild-type strain QM6a and mutant strains NG14 and RUT-C30. Both slight and remarkable alterations in enzyme function due to growth variables such as $\mathrm{pH}$, temperature, salts, etc. could be rapidly identified [47]. This property can be applied to differentiate existing and recently identified microorganisms with highly valuable biomass degrading properties. This could be employed to enhance and optimize enzyme cocktails for lignocellulosic biomass processing [48]. Xuan et al. [49], developed a two-phase simultaneous saccharification and fermentation (TPSSF) process for cost effective conversion of aqueous ammonia pretreated corn stover to ethanol. They integrated pentoses (xylan) and hexoses (glucose) utilization by E. coli K011 and S. cerevisiae D5A strains in the first and second phases, respectively and were able to achieve highest ethanol concentration of $22.3 \mathrm{~g} / \mathrm{L}(84 \%$ theoretical yield). So, besides increasing the bioethanol yield the problem of glucose inhibition on xylose fermentation could be solved in a single process [49]. Twofold benefits of energy 
production and weed management were achieved when Lantana camara (a weed abundantly available in India) was successfully converted to bioethanol. The delignification of acid pretreated biomass was done using sodium sulfite $(5.0 \% \mathrm{w} / \mathrm{v})$ and sodium chlorite $(3.0 \% \mathrm{w} / \mathrm{v})$ which resulted in about $87.2 \%$ lignin removal. The fermentation of enzymatic and acid hydrolysates yielded 17.7 and 5.16g/L of ethanol with Saccharomyces cerevisiae and Pichia stipitis after 16 and 24h, respectively [50]. In an another study, Karagöz et al. [51] were able to obtain 14.07 g/100 g raw straw and 5.73g ethanol from liquid (additionally) obtained after 5\% alkaline peroxide (at $50{ }^{\circ} \mathrm{C}$ for $1 \mathrm{~h}$ ) pretreatment of rapeseed straw through SVSCF (Same Vessel Saccharification and Cofermentation) processes from Saccharomyces cerevisiae and Pichia stipitis [51].

One of the major limitations of bioethanol production is the recalcitrance of biomass to hydrolysis, which is chiefly due to lignin. Thus, manipulation of the lignin biosynthesis pathway to reduce recalcitrance seems to be a better approach for improving bioethanol production from lignocellulosic biomass. Recently, Wuddineh et al. [52] observed that ectopic overexpression of Knotted1 transcription factor, PvKN1 (a putative ortholog of maize KN1) altered growth in switchgrass, especially in early developmental stages. Their study suggests that PvKN1 broadly regulates the lignin biosynthesis pathway via modulation of GA (gibberellic acid) signaling. In the transgenic lines the overexpression of PvKN1 not only reduced the lignin content but also altered the expression of cellulose and hemicellulose biosynthetic genes thereby increasing the efficiency of sugar release [52]. A similar work published before by Voorend et al. [53] suggested that the overexpression of GA20-OXIDASE1 in maize increased the saccharification of modified biomass after $\mathrm{NaOH}$ pretreatment [53]. Therefore, apart from developing pretreatment technologies and composing enzyme consortiums, lignocellulose feedstock improvement also seems to be a feasible strategy to enhance bioethanol yields [54-58].

\section{Conclusion}

Development of an alternate and sustainable fuel source is a major concern of all nations in the world. Bioethanol derived from various agro-industrial wastes finds great prospective to fulfill the aim of designing a process for continuous supply of energy. India being an agricultural economy has plenty supply of agricultural waste throughout the year which can be utilized for production of second generation bio-ethanol. Development of new strategies towards maximum liberation and utilization of sugars from agrowaste remain a priority for cost effective ethanol production. Ethanol production from agricultural waste is even more beneficial as it also gives a solution to disposal of agricultural waste, which is major problem across the world. The strategies discussed above for bioethanol production have a very low success rate in terms of full commercialization. In this scenario, high throughput techniques, such as next generation sequencing, synthetic biology and metagenomics can be anticipated to explore novel enzymes with increased activity and tolerance to stresses so as to produce high quality ethanol from varied substrates. This chapter highlights different strategies like simultaneous saccharification and fermentation, separate hydrolysis and fermentation, separate hydrolysis and co-fermentation and consolidated saccharification and fermentation and discusses in detail recent advances for saccharification and fermentation of lignocellulosic waste for production of ethanol. In conclusion, lignocelluloses hold significant potential to meet the increasing energy demand of the modern world. They form valuable sources of energy to overcome our excessive dependence on petroleum-based fuels that are known to cause environmental pollution and global climate change.

\section{Acknowledgement}

Authors are thankful to Science and Engineering Research Board, New Delhi, India, for providing financial assistance.

\section{Conflict of Interest}

The authors declare that there is no conflict of interests regarding the publication of this paper.

\section{References}

1. Behera S, Singh R, Arora R, Sharma NK, Shukla M, et al. (2015) Scope of algae as third generation biofuels. Front Bioeng Biotechnol 2: 90.

2. Dragone G, Fernandes B, Vicente AA, Teixeira JA (2010) Third generation biofuels from microalgae. In: Mendez-Vilas A, (Ed.), Current Research, Technology and Education Topics in Applied Microbiology and Microbial Biotechnology. (Madrid: Formatex) pp. 1355-1366.

3. Burk MJ (2010) Sustainable production of industrial chemicals from sugars. International Sugar Journal 112: 30-35.

4. Chiaramonti D. Overview on biofuel technologies: feedstocks and processes development, pp. 1-7.

5. Global BP (2011) Statistical Review of World Energy.

6. Aro EM (2016) From first generation biofuels to advanced solar biofuels. Ambio 45(Suppl 1): S24-S31.

7. Zhao XQ Zi LH, Bai FW, Lin HL, Hao XM, et al. (2012) Bioethanol from lignocellulosic biomass. Adv Biochem Eng Biotechnol 128: 25-51.

8. Cheng JJ, Timilsina GR (2011) Status and barriers of advanced biofuel technologies: a review. Renewable Energy 36(12): 3541-3549.

9. Scully SM, Orlygsson J (2015) Recent Advances in second generation ethanol production by thermophilic bacteria. Energies 8(1): 1-30.

10. Rastogi M, Shrivastava S (2017) Recent advances in second generation bioethanol production: An insight to pretreatment, saccharification and fermentation processes. Renewable and Sustainable Energy Reviews 80: 330-340.

11. Kang Q, Appels L, Tan T, Dewil R (2014) Bioethanol from lignocellulosic biomass: current findings determine research priorities. The Scientific World Journal.

12. Vohra M, Manwar J, Manmode R, Padgilwar S, Patil S (2014) Bioethanol production: feedstock and current technologies. Journal of Environmental Chemical Engineering 2(1): 573-584.

13. Jambo SA, Abdulla R, Azhar SHA, Marbawi H, Gansau JA, et al. (2016) A review on third generation bioethanol feedstock. Renewable and Sustainable Energy Reviews 65: 756-769.

14. Olofsson K, Bertilsson M, Lidén G (2008) A short review on SSF - an interesting process option for ethanol production from lignocellulosic feedstocks. Biotechnology for Biofuels 1(1): 7. 
15. Ferreira V, de Oliveira Faber M, da Silva Mesquita S, Pereira Junior N (2010) Simultaneous saccharification and fermentation process of different cellulosic substrates using a recombinant Saccharomyces cerevisiae harbouring the $\beta$-glucosidase gene. Electronic Journal of Biotechnology. 13(2)

16. Hasunuma T, Kondo A (2012) Consolidated bioprocessing and simultaneous saccharification and fermentation of lignocellulose to ethanol with thermotolerant yeast strains. Process Biochemistry 47(9): 1287-1294.

17. Sánchez ÓJ, Cardona CA (2008) Trends in biotechnological production of fuel ethanol from different feedstocks. Bioresour Technol 99(13): 5270595.

18. Koppram R, Nielsen F, Albers E, Lambert A, Wännström S, et al. (2013) Simultaneous saccharification and co-fermentation for bioethanol production using corncobs at lab, PDU and demo scales. Biotechnology for Biofuels 6: 2.

19. Jouzani GS, Taherzadeh MJ (2015) Advances in consolidated bioprocessing systems for bioethanol and butanol production from biomass: a comprehensive review. Biofuel Research Journal 5: 152-195.

20. Parisutham V, Kim TH, Lee SK (2014) Feasibilities of consolidated bioprocessing microbes: from pretreatment to biofuel production Bioresour Technol 161: 431-440.

21. Maki ML, Armstrong L, Leung KT, Qin W (2013) Increased expression of $\beta$-glucosidase in Clostridium thermocellum 27405 significantly increases cellulase activity. Bioengineered 4(1): 15-20.

22. Kumagai A, Kawamura S, Lee SH, Endo T, Rodriguez M, et al. (2014) Simultaneous saccharification and fermentation and a consolidated bioprocessing for Hinoki cypress and Eucalyptus after fibrillation by steam and subsequent wet disk milling. Bioresour Technol 162: 89-95.

23. Tian L, Papanek B, Olson DG, Rydzak T, Holwerda EK, et al. (2016) Simultaneous achievement of high ethanol yield and titer in Clostridium thermocellum. Biotechnology for Biofuels 9: 116.

24. Jin M, Balan V, Gunawan C, Dale BE (2011) Consolidated bioprocessing (CBP) performance of Clostridium phytofermentans on AFEX-treated corn stover for ethanol production. Biotechnol Bioengg 108(6): 1290-1297.

25. Li Y, Tschaplinski TJ, Engle NL, Hamilton CY, Rodriguez M, et al. (2012) Combined inactivation of the Clostridium cellulolyticum lactate and malate dehydrogenase genes substantially increases ethanol yield from cellulose and switchgrass fermentations. Biotechnol Biofuels 5(1): 2.

26. Shaw AJ, Covalla SF, Miller BB, Firliet BT, Hogsett DA, et al. (2012) Urease expression in a Thermoanaerobacterium saccharolyticum ethanologen allows high titer ethanol production. Metab Eng 14(5): 528-532.

27. Chung D, Cha M, Snyder EN, Elkins JG, Guss AM, et al. (2015) Cellulosic ethanol production via consolidated bioprocessing at $75^{\circ} \mathrm{C}$ by engineered Caldicellulosiruptor bescii. Biotechnology for Biofuels 8: 163

28. Shin HD, Wu J, Chen R (2014) Comparative engineering of Escherichia coli for cellobiose utilization: hydrolysis versus phosphorolysis. Metab Eng 24: 9-17.

29. Luo Z, Zhang Y, Bao J (2014) Extracellular secretion of $\beta$-glucosidase in ethanologenic $E$. coli enhances ethanol fermentation of cellobiose. Appl Biochem Biotechnol 174(2): 772-783.

30. Wu B, He MX, Feng H, Shui ZX, Tang XY, et al. (2014) Construction of a novel secretion expression system guided by native signal peptide of PhoD in Zymomonas mobilis. Biosci Biotechnol Biochem 78(4): 708-713.

31. Ali SS, Nugent B, Mullins E, Doohan FM (2013) Insights from the fungus Fusarium oxysporum point to high affinity glucose transporters as targets for enhancing ethanol production from lignocellulose. PLoS One 8(1): e54701.

32. Huang J, Chen D, Wei Y, Wang Q Li Z, et al. (2014) Direct ethanol production from lignocellulosic sugars and sugarcane bagasse by a recombinant
Trichoderma reesei strain HJ48. Scientific World Journal 2014: 798683.

33.Zerva A, Savvides AL, Katsifas EA, Karagouni AD, Hatzinikolaou DG (2014) Evaluation of Paecilomyces variotii potential in bioethanol production from lignocellulose through consolidated bioprocessing. Bioresour Technol 162: 294-299.

34. Hossain SM (2013) Bioethanol fermentation from non-treated and pretreated corn stover using Aspergillus oryzae. Chemical Engineering Research Bulletin 16(1): 33-44.

35. Hu N, Yuan B, Sun J, Wang SA, Li FL (2012) Thermotolerant Kluyveromyces marxianus and Saccharomyces cerevisiae strains representing potentials for bioethanol production from Jerusalem artichoke by consolidated bioprocessing. Appl Microbiol Biotechnol 95(5): 1359-1368.

36. Chang JJ, Ho FJ, Ho CY, Wu YC, Hou YH, et al. (2013) Assembling a cellulose cocktail and a cellodextrin transporter into a yeast host for CBP ethanol production. Biotechnol Biofuels 6(1): 19.

37. Liu ZL, Weber SA, Cotta MA, Li SZ (2012) A new $\beta$-glucosidase producing yeast for lower cost cellulosic ethanol production from xylose-extracted corncob residues by simultaneous saccharification and fermentation. Bioresour Technol 104: 410-416.

38. Watanabe T, Watanabe I, Yamamoto M, Ando A, Nakamura T (2011) A UV-induced mutant of Pichia stipitis with increased ethanol production from xylose and selection of a spontaneous mutant with increased ethanol tolerance. Bioresour Technol 102(2): 1844-1848.

39. Puseenam A, Tanapongpipat S, Roongsawang N (2015) Co-expression of endoxylanase and endoglucanase in Scheffersomyces stipitis and its application in ethanol production. Appl Biochem Biotechnol 177(8): 1690-1700.

40. Yamada R, Yamakawa S, Tanaka T, Ogino C, Fukuda H, et al. (2011) Direct and efficient ethanol production from high-yielding rice using a Saccharomyces cerevisiae strain that express amylases. Enzyme Microb Technol 48(4-5): 393-396.

41. Sakamoto T, Hasunuma T, Hori Y, Yamada R, Kondo A (2012) Direct ethanol production from hemicellulosic materials of rice straw by use of an engineered yeast strain codisplaying three types of hemicellulolytic enzymes on the surface of xylose utilizing Saccharomyces cerevisiae cells. J Biotechnol 158(4): 203-210.

42. Fan LH, Zhang ZJ, Mei S, Lu YY, Li M, et al. (2016) Engineering yeast with bifunctional minicellulosome and cellodextrin pathway for co-utilization of cellulose-mixed sugars. Biotechnology for Biofuels 9: 137.

43. Brethauer S, Studer MH (2014) Consolidated bioprocessing of lignocellulose by a microbial consortium. Energy and Environmental Science 7: 1446-1453.

44. Rubin EM (2008) Genomics of cellulosic biofuels. Nature 454(7206): 841-845.

45. Willems LI, Overkleeft HS, van Kasteren SI (2014) Current developments in activity based protein profiling. Bioconjug Chem 25(7): 1181-1191.

46. Chauvigne-Hines LM, Anderson LN, Weaver HM, Brown JN, Koech PK, et al. (2012) Suite of activity-based probes for cellulose-degrading enzymes. J Am Chem Soc 134(50): 20521-20532.

47. Anderson LN, Culley DE, Hofstad BA, Chauvigne-Hines LM, Zink EM, et al. (2013) Activity- based protein profiling of secreted cellulolytic enzyme activity dynamics in Trichoderma reesei QM6a, NG14, and RUTC30. Mol Biosyst 9(12): 2992-3000.

48. Liu Y, Fredrickson JK, Sadler NC, Nandhikonda P, Smith RD, et al. (2015) Advancing understanding of microbial bioenergy conversion processes by activity-based protein profiling. Biotechnol Biofuels 8: 156

49. Li X, Kim TH, Nghiem NP (2010) Bioethanol production from corn stover using aqueous ammonia pretreatment and two-phase simultaneous saccharification and fermentation (TPSSF). Bioresour Technol 101(15): 5910-5916. 
50. Kuhad RC, Gupta R, Khasa YP, Singh A (2010) Bioethanol production from Lantana camara (red sage): pretreatment, saccharification and fermentation. Bioresour Technol 101(21): 8348-8354.

51. Karagöz P, Rocha IV, Özkan M, Angelidaki I (2012) Alkaline peroxide pretreatment of rapeseed straw for enhancing bioethanol production by Same Vessel Saccharification and Co-Fermentation. Bioresour Technol 104: 349-357.

52. Wuddineh WA, Mazarei M, Zhang JY, Turner GB, Sykes RW, et al. (2016) Identification and overexpression of a Knotted1-Like Transcription Factor in switchgrass (Panicum virgatum L.) for lignocellulosic feedstock improvement. Front Plant Sci 7: 520.

53. Voorend W, Nelissen H, Vanholme R, De Vliegher A, Van Breusegem F, et al. (2016) Overexpression of GA20-OXIDASE1 impacts plant height, biomass allocation and saccharification efficiency in maize. Plant Biotechnol J 14(3): 997-1007.

54. Chung D, Cha M, Snyder EN, Elkins JG, Guss AM, Westpheling J (2015)
Cellulosic ethanol production via consolidated bioprocessing at $75^{\circ} \mathrm{C}$ by engineered Caldicellulosiruptor bescii. Biotechnol Biofuels 8: 163.

55. Favaro L, Viktor MJ, Rose SH, Viljoen-Bloom M, van Zyl WH, et al. (2015) Consolidated bioprocessing of starchy substrates into ethanol by industrial Saccharomyces cerevisiae strains secreting fungal amylases. Biotechnol Bioeng 112(9): 1751-1760.

56. Gong Y, Tang G, Wang M, Li J, Xiao W, et al. (2014) Direct fermentation of amorphous cellulose to ethanol by engineered Saccharomyces cerevisiae coexpressing Trichoderma viride EG3 and BGL1. J Gen Appl Microbiol 60(5): 198-206.

57. High Efficiency Consolidated Bioprocess Technology for Lignocellulose Ethanol HYPE.

58. Wang D, Li FL, Wang SA (2016) Engineering a natural Saccharomyces cerevisiae strain for ethanol production from inulin by consolidated bioprocessing. Biotechnology for Biofuels 9: 96.
Creative Commons Attribution 4.0

International License

For possible submissions Click Here
Submit Article
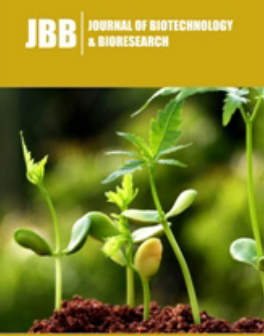

\section{Journal of Biotechnology \& Bioresearch}

\section{Benefits of Publishing with us}

- High-level peer review and editorial services

- Freely accessible online immediately upon publication

- Authors retain the copyright to their work

- Licensing it under a Creative Commons license

- Visibility through different online platforms 